Article

\title{
Development and Characterization of New Topical Hydrogels Based on Alpha Lipoic Acid-Hydrotalcite Hybrids
}

\author{
Cinzia Pagano ${ }^{(D)}$, Paola Calarco $\mathbb{D}^{D}$, Maria Rachele Ceccarini $\mathbb{D}^{\mathbb{D}}$, Tommaso Beccari $\mathbb{D}^{\mathbb{D}}$, \\ Maurizio Ricci ${ }^{(D)}$ and Luana Perioli *(D) \\ Dipartimento di Scienze Farmaceutiche, Università degli Studi di Perugia, 06123 Perugia, Italy; \\ cinzia.pagano@unipg.it (C.P.); paola.calarco@unipg.it (P.C.), chele@hotmail.it (M.R.C.); \\ tommaso.beccari@unipg.it (T.B.); maurizio.ricci@unipg.it (M.R.) \\ * Correspondence: luana.perioli@unipg.it; Tel.: +39-075-5855133; Fax: +39-075-5855123
}

Received: 15 May 2019; Accepted: 15 June 2019; Published: 18 June 2019

check for updates

\begin{abstract}
Alpha lipoic acid (ALA) is a well-known anti-aging compound. The activity of this molecule is limited by two important factors: (i) The low stability to oxidation and thermal processes and (ii) the low solubility. Particularly the latter limits ALA formulation in hydrophilic bases. The purpose of this paper is to present a new technological approach to stabilize lipoic acid in topical hydrogels for cosmetic use. With this aim, ALA was intercalated in two different lamellar anionic clays (hydrotalcites), $\mathrm{MgAl}$ and $\mathrm{ZnAl}$, obtaining the hybrids MgAl-ALA and ZnAl-ALA. The intercalation allows to obtain a more manageable product in comparison to raw ALA. After the preliminary characterization, hydrogels containing the hybrids were prepared and characterized, also in comparison to the commercial product Tiobec ${ }^{\circledR}$ in terms of rheological properties, stability to temperature and centrifugation, release, and cytotoxicity. The obtained results highlighted that the hydrogel containing MgAl-ALA is a suitable alternative to the products currently available on the market.
\end{abstract}

Keywords: lipoic acid; hydrotalcite; intercalation product; hybrids; hydrogel; stability; rheology

\section{Introduction}

R-(+)-alpha-lipoic acid (ALA) is a naturally occurring compound, found in animal-derived foods, such as red meat and liver, heart and kidney, and plants such as spinach, broccoli, tomatoes, brussel sprouts, potatoes, garden peas, and rice bran [1].

ALA is widely used in cosmetic and dermatological products because of its many favorable effects on the skin. It acts as an essential co-factor of the mitochondrial multi-enzyme complex and thus plays an important role in energy metabolism participating in different mechanisms such as cell growth, oxidation of carbohydrates, amino acids, and regulation of mitochondrial redox balance [2]. In fact, it is a potent antioxidant by scavenging and eliminating free radicals [3-5]. ALA displays an excellent scavenging activity against the hydroxyl radical (HO·) responsible for hydroxylation of various biomolecules by reduction of unsaturated bonds present in their structures [6,7]. It was observed that ALA is able to reduce cell injury and protect fibroblasts against irradiation-induced cytotoxicity showing interesting applications in the attenuation of the side effects associated to cancer radiation therapy [8].

Moreover, ALA demonstrated to possess anti-inflammatory activity reducing the levels of the tumor necrosis factor (TNF)- $\alpha$, interleukin (IL)-1 beta (IL-1 $\beta$ ), and IL-6 [9-11].

Unfortunately ALA is unstable against oxidation and temperature undergoing to polymerization with consequent loss of its bioactivity and formation of unpleasant sulfurous odor [12,13]. 
Many technological strategies have been purposed in order to improve ALA stability as nanoencapsulation [14-16], co-formulation with stabilizing molecules [17], formulation in nanostructured lipid carriers [18], complexation with cyclodextrins [19], complexation with chitosan [20], incorporation in alginate gel beads [21], and encapsulation in amylose helices [22].

The aim of this work was to purpose a new suitable technology able to improve ALA stability and to realize a new topical formulation which can represent valuable alternative to the creams currently available on the market.

The purposed strategy consists in ALA intercalation (guest) into inorganic lamellar anionic clays (host) as the hydrotalcites (HTlc), able to host and protect an organic moiety (guest) in molecular form $[23,24]$. These are versatile materials largely used in health field as they work contemporaneously as carrier for active ingredients, stabilizer, and rheological agent [25-28]. The latter aspect is very important particularly when the intercalation products of HTlc are introduced in semisolid formulations. In fact, HTlc acts to enhance different properties of a topical formulation working as a thickening agent, texturizing agent, and flowing agent [29-31].

The rheological properties influence the "skin fell" of a topical formulation, hence the acceptability of the user. This aspect become very important especially when the developed formulations should be applied on compromised skins as that of patients under radiation therapy.

For this work, hydrotalcites based on magnesium and aluminum (MgAl-HTlc) and zinc and aluminum (ZnAl-HTlc) in chloride form were used as precursors for the preparation of HTlc-ALA hybrids.

\section{Materials and Methods}

\subsection{Materials}

Alpha $(\alpha)$-lipoic acid (ALA) was purchased from Olon S.p.A. - P\&R Group (Rodano, Milano, Italy). Sorbitol and glycerol were purchased from A.C.E.F. (Fiorenzuola D'Arda, Italy). Aluminum chloride esahydrate, calcium chloride, magnesium chloride esahydrate, potassium dihydrogen phosphate, sodium carbonate decahydrate, and sodium hydrogen phosphate anhydrous (Carlo Erba, Cornaredo, Milano, Italy) were supplied by DueM (Perugia, Italy). Zinc oxide (Caelo, Hilden, North Rhine Westphalia, Germany) was purchased from Comifar (Perugia, Italy). Di-sodium hydrogen phosphate dodecahydrate was purchased from Panreac (Castellar del Vallès, Barcelona, Spain). Hydroxyethylcellulose (HEC), Natrosol ${ }^{\circledR} 250 \mathrm{HX}$ and sodium carboxymethycellulose (NaCMC) were supplied by Hercules incorporated-Aqualon division (Wilmington, DE, USA). Ultrapure water was obtained by reverse osmosis process in a MilliQ system Millipore (Rome, Italy). Other reagents and solvents were of analytical grade and used without further purification.

The commercial formulation Tiobec ${ }^{\circledR}$ (ALA 5\%, Laborest Italia S.p.A., Nerviano, MI, Italy), available on the Italian market, was purchased in pharmacy.

The fluid used in the release studies as acceptor medium was a mixture of methanol (25\%) with phosphate buffer $\mathrm{pH} 5.5(75 \%)$. The latter was prepared according to $\mathrm{Ph}$. Eur. $9^{\text {th }}$ Ed procedure. As donor fluid, it was used a solution of potassium carbonate $0.025 \mathrm{M}$ [32].

\subsection{Synthesis of Hydrotalcites}

$\mathrm{MgAl}-\mathrm{CO}_{3}$ and $\mathrm{ZnAl}-\mathrm{CO}_{3}$ were obtained by coprecipitation of $\mathrm{Mg}(\mathrm{II}) / \mathrm{Zn}(\mathrm{II})-\mathrm{Al}(\mathrm{III})$ accomplished by the hydrolysis of urea [33]. The chloride ( $\mathrm{MgAl}-\mathrm{Cl}$ and $\mathrm{ZnAl}-\mathrm{Cl})$ forms were obtained treating the solid with diluted solutions of the corresponding mineral acid [33].

\subsection{Preparation of Hydrotalcite-ALA Hybrids}

ALA was converted in the sodium salt $\left(\mathrm{ALA}^{-} \mathrm{Na}^{+}\right)$using an equimolar water solution of $\mathrm{NaOH}$ $0.1 \mathrm{M}$. The intercalation products were obtained using $\mathrm{MgAl}-\mathrm{HTlc}-\mathrm{Cl}(\mathrm{MgAl}-\mathrm{Cl})$ and $\mathrm{ZnAl}-\mathrm{HTlc}-\mathrm{Cl}$ (ZnAl-Cl) as pristine materials. $\mathrm{ZnAl}-\mathrm{Cl}$ or $\mathrm{MgAl}-\mathrm{Cl}\left(\mathrm{HTl} / \mathrm{ALA}^{-} \mathrm{Na}^{+}\right.$molar ratio 2:1) was dispersed in 
a hydroalcoholic solution (ethanol/water 1:11) of $\mathrm{ALA}^{-} \mathrm{Na}^{+}(18.76 \mathrm{mg} / \mathrm{mL})$. The obtained suspension was kept under magnetic stirring $(600 \mathrm{rpm})$ for $24 \mathrm{~h}$. Then, the corresponding solids, MgAl-HTlc-ALA (MgAl-ALA) and ZnAl-HTlc-ALA (ZnAl-ALA), were recovered by centrifugation, washed with degassed $\left(\mathrm{CO}_{2}\right.$ free $)$ water and dried in oven at $37^{\circ} \mathrm{C}$ for $48 \mathrm{~h}$.

\subsection{X-ray Analysis}

Powder X-ray diffraction patterns (XRPD) were collected with a Philips X'Pert PRO MPD diffractometer operating at $40 \mathrm{kV}$ and $40 \mathrm{~mA}$, with a step size $0.03^{\circ}$ 2theta, and step scan $40 \mathrm{~s}, \mathrm{using} \mathrm{Cu}$ $\mathrm{K} \alpha$ radiation and an $\mathrm{X}^{\prime}$ Celerator detector.

\subsection{Metal Composition Determination}

Metal analyses were performed by Varian 700-ES series Inductively Coupled Plasma-Optical Emission Spectrometers (ICP-OES) using solutions prepared by dissolving the samples in some drops of concentrated $\mathrm{HNO}_{3}$ solution and properly diluted with water.

\subsection{Thermogravimetric Analysis (TGA)}

Thermogravimetric analysis (TGA) were performed by a Netzsch STA 449C apparatus, in air flow and heating rate of $10{ }^{\circ} \mathrm{C} / \mathrm{min}$ to determine the weight loss (water and drug) as a function of increasing temperature.

\subsection{Single Particle Optical Sensing (SPOS) Analysis}

An Accusizer C770 (PSS Inc., Santa Barbara, CA, USA) with the SPOS technique "Single Particle Optical Sensing" was used to determine the size distribution of the different HTlc samples. The analyses were carried out in triplicate and the sizes were expressed as cumulative area distributions. D10, D50, and D90 are defined as the size values corresponding to cumulative distributions at 10\%,50\%, and 90\%, respectively. These represent the particle sizes below which $10 \%, 50 \%$, and $90 \%$, respectively, of the samples' particles lie.

\subsection{Differential Scanning Calorimetry (DSC)}

DSC analyses were performed using an automatic thermal analyzer (Mettler Toledo DSC821e, Mettler Toledo $\mathrm{GmbH}$, Schwerzenbach, Switzerland) and indium standard for temperature calibrations. Holed aluminum pans were employed in the experiments for all samples and an empty pan, prepared in the same way, was used as a reference. Samples were weighted directly into the aluminum pans and the thermal analyses were conducted, at a heating rate of $5^{\circ} \mathrm{C} / \mathrm{min}$, from 30 to $100{ }^{\circ} \mathrm{C}$.

\subsection{Morphological Characterization by Scanning Electron Microscopy Analysis (SEM)}

SEM micrographs were taken by a FE-SEM LEO 1525 Zeiss-LEO Electron Microscopy Inc., One Zeiss Drive (Thornwood, NY, USA). The samples (powders) were by deposited on the stab, previously coated with carbon tape, under nitrogen flow. The raw powder was not sifted. Before observation, the samples were sputtered and coated with chromium for 5 min under an argon atmosphere.

The micrographs were taken at magnification of $10.00 \mathrm{KX}$, voltage (EHT) $15.00 \mathrm{kV}$, work distance (WD) $8.2 / 8.3 \mathrm{~mm}$.

\subsection{Flow Properties Determination}

The flow properties of the pristine $\mathrm{MgAl}-\mathrm{Cl}$ and $\mathrm{ZnAl}-\mathrm{Cl}$ and the corresponding intercalation products MgAl-ALA and ZnAl-ALA were determined by Carr's compressibility index [34] and Hausner's ratio [35] calculation following the procedure described in the European Pharmacopoeia (Ph. Eur. $9^{\text {th }}$ Ed.) by means of the determination of the apparent volume before and after powder 
settling [36], by using a tap density instrument (ERWEKA GmbH SVM 101/201, Heusenstamm Germany). The measurements were taken in triplicate, each result represents an average of three measurements and the error was expressed as standard deviation (SD). The Carr's compressibility index (CI) was calculated following Equation (1) while the Hausner ratio (HR) was calculated applying Equation (2):

$$
\begin{gathered}
C I=\frac{\left(V_{0}-V_{f}\right)}{\left(V_{0}\right)} * 100 \\
H R=\frac{V_{0}}{V_{f}}
\end{gathered}
$$

\subsection{Cell Culture}

In-house established human primary fibroblasts were kindly supplied by Dr. A. Dardis (Regional Coordinator Centre for Rare Diseases, AMC Hospital of Udine, Italy). Cells were cultured according to standard procedures in Dulbecco's modified Eagle's medium (DMEM), supplemented with 10\% heat-inactivated Fetal Bovine Serum (FBS), 2 mM of L-glutamine and antibiotics (100 U/mL penicillin, $100 \mu \mathrm{g} / \mathrm{mL}$ streptomycin). The cells were maintained in a cell incubator at $37^{\circ} \mathrm{C}$ in a humidified atmosphere containing $5 \% \mathrm{CO}_{2}$. All studies on human primary fibroblasts were carried out using cells from passages 4-12. In all experiments, untreated cells were used as negative controls.

\subsection{Samples Preparation}

MgAl-ALA or ZnAl-ALA (amount corresponding to $5 \mathrm{mg}$ of ALA) was dispersed in $5 \mathrm{~mL}$ of DMEM, vortexed and incubated at $37^{\circ} \mathrm{C}$ for $24 \mathrm{~h}$, then centrifuged for $10 \mathrm{~min}$ at $4000 \mathrm{rpm}$. The supernatant was used for cell incubation.

\subsection{MTT Assay}

Cellular viability was assessed by the reduction of MTT to formazan [37]. The human primary fibroblasts were seeded onto 96-well plate at a density of $3 \times 10^{3}$ cells/well and $1 \times 10^{4}$ cells/well respectively with DMEM complete medium. After $24 \mathrm{~h}$ fresh complete medium was replaced for treatment (for $24 \mathrm{~h}$ ) with different volumes of DMEM previous incubated with the hybrids (par. 2.12 Sample preparation) diluted with culture medium to obtain a final volume of $180 \mu \mathrm{L}$. After $24 \mathrm{~h}$ the MTT reagent was dissolved in PBS 1X, and added to the culture at $0.5 \mathrm{mg} / \mathrm{mL}$ final concentration $(20 \mu \mathrm{L})$. After $3 \mathrm{~h}$ incubation at $37^{\circ} \mathrm{C}$, the supernatant was carefully removed and formazan salt crystals were dissolved in $200 \mu \mathrm{L}$ DMSO added to each well. After 30 min the absorbance (OD) values were measured spectrophotometrically at $540 \mathrm{~nm}$ using an automatic microplate reader (Eliza MAT 2000, DRG Instruments GmbH, Marburg, Germany). Each experiment was performed two times in triplicate. Cell viability was expressed as a percentage relative to that of the control cells, as described previously [38].

\subsection{Thermal Stability of ALA Samples using DSC}

A fixed amount of MgAl-ALA (11.93 mg), ZnAl-ALA (17.48 mg) containing $5 \mathrm{mg}$ of ALA and crystalline ALA (5 mg) was incubated in a closed chamber maintained for $48 \mathrm{~h}$ at $25{ }^{\circ} \mathrm{C}$ under $\sim 97 \%$ relative humidity conditions (imitating unfavorable storage conditions), obtained using a saturated water solution of $\mathrm{K}_{2} \mathrm{SO}_{4}$ [39]. Subsequently, the samples were analyzed by DSC analysis using the method reported in par. 2.8 of this section.

\subsection{Preparation of Hydrogels}

Hydrogels containing ALA in free form or as intercalation product (MgAl-ALA or ZnAl-ALA) were prepared according to the recipe reported in the Farmacopea Ufficiale Italiana (F.U. XII Ed.) in the 
section "Semisolid Formulations Intended for Skin Application" [40]. Many prototypes were prepared in order to find the most suitable composition, making changes to the original recipe (Table 1).

Table 1. First prototypes hydrogels composition.

\begin{tabular}{cccccc}
\hline & \multicolumn{5}{c}{ Composition } \\
\cline { 2 - 6 } Hydrogel & $\begin{array}{c}\text { NaCMC } \\
\mathbf{( \% )}\end{array}$ & $\begin{array}{c}\text { HEC } \\
\mathbf{( \% )}\end{array}$ & $\begin{array}{c}\text { Sorbitol } \\
\mathbf{( \% )}\end{array}$ & $\begin{array}{c}\text { HTlc-Cl } \\
\mathbf{( \% )}\end{array}$ & $\begin{array}{c}\text { Water } \\
\mathbf{( \% )}\end{array}$ \\
\hline P1 & 5.00 & - & 10.00 & 17.48 & 67.52 \\
P2 & 3.50 & - & 10.00 & 17.48 & 69.02 \\
P3 & 3.00 & - & 10.00 & 17.48 & 69.52 \\
P4 & 2.50 & - & 10.00 & 17.48 & 70.02 \\
P5 & - & 2.50 & 10.00 & 17.48 & 70.02 \\
P6 & - & 2.00 & 10.00 & 17.48 & 70.52 \\
P7 & - & 1.75 & 10.00 & 17.48 & 70.77 \\
P8 & - & 1.25 & 10.00 & 17.48 & 71.27 \\
\hline
\end{tabular}

ALA, or the intercalation product (hybrid), was mixed in mortar with HEC and sorbitol, at last water was added under stirring until complete polymer hydration.

\subsection{Rheological Measurements}

Viscometry measurements (viscosity and yield stress measured at $25^{\circ} \mathrm{C}$ and $32^{\circ} \mathrm{C}$ ) of formulations were performed by a Stresstech $\mathrm{HR}$ (Reologica Instruments AB, Milano, Italy) rheometer with cone-plate geometry (diameter of $40 \mathrm{~mm}$ angle $1^{\circ}$ ). Samples were carefully applied to the lower plate using a spatula to avoid formulation shearing and air bubble formation. The measurements were performed submitting the samples to a shear stress range solicitation of $1-10^{3} \mathrm{~Pa}$, torque $1.67 \cdot 10^{-5}-1.67 \cdot 10^{-2} \mathrm{Nm}$ (increase of $8.81 \cdot 10^{-4} \mathrm{Nm} / 2.1 \mathrm{~s}$ ), time of the analysis $45 \mathrm{~s}$ (one point $/ 2.1 \mathrm{~s}$ ).

\subsection{Spreadability Measurements}

One gram of hydrogel formulation was pressed between two horizontal plates $20 \mathrm{~cm}$ square and its diameter (spread diameter) was measured after one min. Under these experimental conditions, they were applied the following terms: Semi-stiff creams to samples with a spread diameter $\leq 50 \mathrm{~mm}$ and semifluid creams to those with a spread diameter $>50 \mathrm{~mm}$ but $<70 \mathrm{~mm}[41,42]$.

\subsection{Optical Microscope Observation}

Hydrogel samples were observed by a Nikon Eclipse 80i optical microscope (Melville, LA, USA).

\subsection{Stability Studies of Hydrogels}

The prepared hydrogels containing free ALA or the intercalation products (Table 2) and Tiobec ${ }^{\circledR}$ were submitted to the following stability studies:

- Accelerated stability studies: The samples were submitted to eight $4{ }^{\circ} \mathrm{C} / 45^{\circ} \mathrm{C}$ cycles. Each cycle consisted in the storage of each sample alternatively at $4{ }^{\circ} \mathrm{C}$ (for $48 \mathrm{~h}$ ) and $45^{\circ} \mathrm{C}$ (for $48 \mathrm{~h}$ ).

- Centrifugation test: the samples were centrifuged at $25^{\circ} \mathrm{C}$ for $20 \mathrm{~min}$ at $3000 \mathrm{rpm}$ (Hettich zentrifugen, Universal $32 \mathrm{R}$ ).

In both cases the samples were evaluated in terms of organoleptical properties: Color, odor, and appearance [43]. 
Table 2. Compositions of the hydrogels prepared.

\begin{tabular}{cccccccc}
\hline & \multicolumn{7}{c}{ Composition } \\
\cline { 2 - 8 } Hydrogel & $\begin{array}{c}\text { Free } \\
\text { ALA } \\
(\%)\end{array}$ & $\begin{array}{c}\text { MgAl-ALA } \\
(\mathbf{\%})\end{array}$ & $\begin{array}{c}\text { ZnAl-ALA } \\
\mathbf{( \% )}\end{array}$ & $\begin{array}{c}\text { HTlc-Cl } \\
\mathbf{( \% )}\end{array}$ & $\begin{array}{c}\text { HEC } \\
\mathbf{( \% )}\end{array}$ & $\begin{array}{c}\text { Sorbitol } \\
\mathbf{( \% )}\end{array}$ & $\begin{array}{c}\text { Water } \\
(\mathbf{\%})\end{array}$ \\
\hline ALA-H & 5 & - & - & 17.48 & 1.75 & 10.00 & 70.77 \\
MgAl-ALA-H & - & 11.93 & - & 5.55 & 1.75 & 10.00 & 70.77 \\
ZnAl-ALA-H & - & - & 17.48 & - & 1.75 & 10.00 & 70.77 \\
\hline
\end{tabular}

\subsection{In Vitro Release Studies}

For this investigation, a vertical Franz diffusion cell was used (PermeGear, Inc., Bethlehem, PA, USA, diameter $20 \mathrm{~mm}$ ). It consists of two chambers separated by a cellulose membrane (Whatman 41, Whatman $\mathrm{GmbH}$, Dassel, Germany): a donor chamber and a receptor chamber. The receptor chamber consists in a water jacketed receptor chamber $(15 \mathrm{ml})$, containing a mixture of methanol and phosphate buffer $\mathrm{pH} 5.5(25 / 75 \% \mathrm{v} / \mathrm{v})$ as acceptor medium maintained at $32{ }^{\circ} \mathrm{C}$ and magnetically stirred at $600 \mathrm{rpm}$. The donor phase consisted of $2 \mathrm{ml}$ of a $0.025 \mathrm{~N} \mathrm{~K}_{2} \mathrm{CO}_{3}$ solution (simulating air $\mathrm{CO}_{2}$ ).

An accurately weighed of hydrogel $\left(200 \mathrm{mg}\right.$ ) was placed on the cellulose membrane (area $3.14 \mathrm{~cm}^{2}$ ) using a spatula and sandwiched between receptor and donor compartments. All openings including donor top and receptor arm were occluded with parafilm to prevent solvent evaporation. At regular time intervals $(15,30,60,120,240,360,480$, and $1440 \mathrm{~min})$ samples of the receiving phase were withdrawn and ALA content was determined by HPLC. All experiments were performed in triplicate, each result represents an average of three measurements and the error was expressed as standard deviation (SD).

\subsection{Quantitative Determination of ALA by HPLC Method}

ALA content in each sample was measured following the HPLC method described in the corresponding monograph of Eur. Ph. $9^{\text {th }}$ Ed. properly modified. A AGILENT 1200-Pegasser liquid chromatography system was used for the analysis.

Separation was achieved using an Agilent Zorbax Eclipse XDB-C18 column (5 $\mu \mathrm{m}$, $150 \mathrm{~mm} \times 4.6 \mathrm{~mm}$ ) maintained at $35^{\circ} \mathrm{C}$ using a column block heater. The mobile phase was a mixture of acetonitrile and a water solution of trifluoroacetic acid $0.1 \%(50: 50 \%, \mathrm{v} / \mathrm{v})$. The mobile phase flow rate was $1.0 \mathrm{~mL} \mathrm{~min}{ }^{-1}$. The injection volume was $20 \mu \mathrm{L}$ and detection was at $330 \mathrm{~nm}$.

\section{Results and Discussion}

\subsection{Hybrid Preparation and Characterization}

ALA was intercalated into HTlc by ion exchange mechanism as described in methods section (par. 2.3). The registration of $\mathrm{X}$ ray patterns of the pristine $\mathrm{MgAl}-\mathrm{Cl}$ and $\mathrm{ZnAl}-\mathrm{Cl}$ and the corresponding intercalation products showed an increase of the interlayer distance from $0.78 \mathrm{~nm}$, typical for the intercalated chloride anion, to $2.2 \mathrm{~nm}$ for both MgAl-ALA (Supplementary Materials Figure S1A) and ZnAl-ALA (Figure S1B) testifying the success of ALA intercalation. In order to establish the exact formula, the hybrids were submitted to ICP-OES and thermogravimetric analyses, the combination of the results obtained allowed to also calculate the final loadings (Table 1):

$\left[\mathrm{Mg}_{0.60} \mathrm{Al}_{0.40}(\mathrm{OH})_{2}\right](\mathrm{Cl})_{0.09}(\mathrm{ALA})_{0.31} \cdot 1.45 \mathrm{H}_{2} \mathrm{O}(41.90 \%$ wt./wt. $)$

$\left[\mathrm{Zn}_{0.62} \mathrm{Al}_{0.38}(\mathrm{OH})_{2}\right](\mathrm{Cl})_{0.15}(\mathrm{ALA})_{0.23} \cdot 1.56 \mathrm{H}_{2} \mathrm{O}(28.60 \%$ wt./wt.).

The intercalation of ALA into HTlc galleries allows to obtain a final product in which the active ingredient is no longer in crystalline form. This was confirmed submitting crystalline ALA and the intercalation products MgAl-ALA and ZnAl-ALA to differential scanning calorimetry analysis. In the thermogram of crystalline ALA reported in Figure 1 it is clearly visible a sharp endothermic peak at 
$66^{\circ} \mathrm{C}(\Delta \mathrm{H}=-136.17 \mathrm{~J} / \mathrm{g})$ corresponding to the melting, following the degradation of the compound [44], while the peak relative to melting point disappears in the case of both intercalation products (Figure 1).

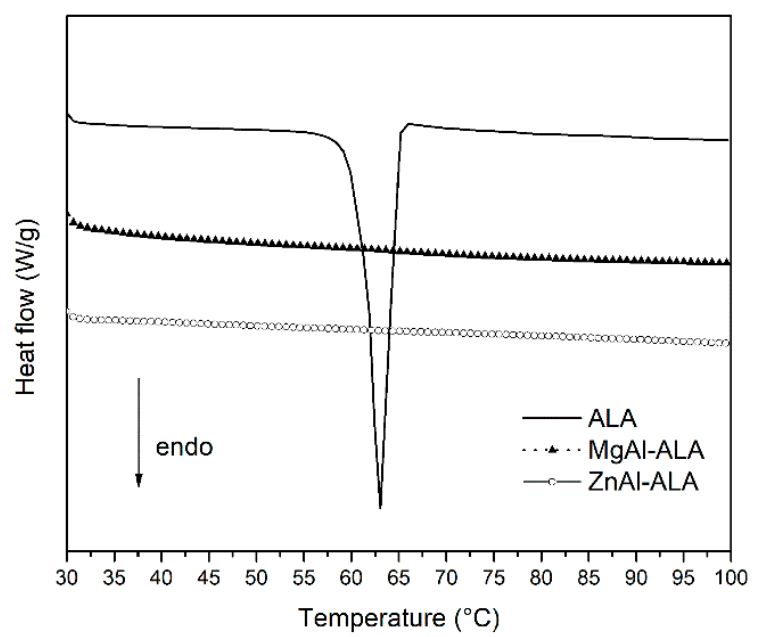

Figure 1. Thermograms registered by differential scanning calorimetry analysis of free crystalline ALA, MgAl-ALA, and ZnAl-ALA.

The particle size analysis (Figure S2) carried out on pristine $\mathrm{HTlc}-\mathrm{Cl}$ and the corresponding intercalation products showed that MgAl-ALA is more polydisperse than ZnAl-ALA (span value 6.6 vs. 1.19 for MgAl-ALA and ZnAl-ALA, respectively). In both cases a modification of the particle size distribution is detectable compared to the precursors. In fact, the median (D50 value) increases from 5.23 to $15.39 \mathrm{~nm}$ for MgAl-ALA and from 6.49 to $10.55 \mathrm{~nm}$ for ZnAl-ALA. Taking into account the median of the hybrids, according to the classification of powders by fineness reported in the Ph. Eur. $9^{\text {th }} \mathrm{Ed}$. [45], both MgAl-ALA and ZnAl-ALA are considered as very fine powders and thus suitable to be introduced in semisolid formulations for skin use.

This is also supported from the morphological analysis performed by scanning electron microscopy (Figure 2). About the morphologic aspect, it is interesting to note that the original features of pristine $\mathrm{MgAl}-\mathrm{Cl}$ and $\mathrm{ZnAl}-\mathrm{Cl}$ (Figure 2A,D, respectively) did not change substantially after the intercalation procedure in both cases. In fact, MgAl-ALA (Figure 2B,C) shows a similar "desert rose like structure" observed in the starting material (Figure 2A). Also in the case of ZnAl-ALA (Figure 2E,F) it is clearly visible a flat and regular structure as that observed in $\mathrm{ZnAl}-\mathrm{Cl}$ (Figure 2D).

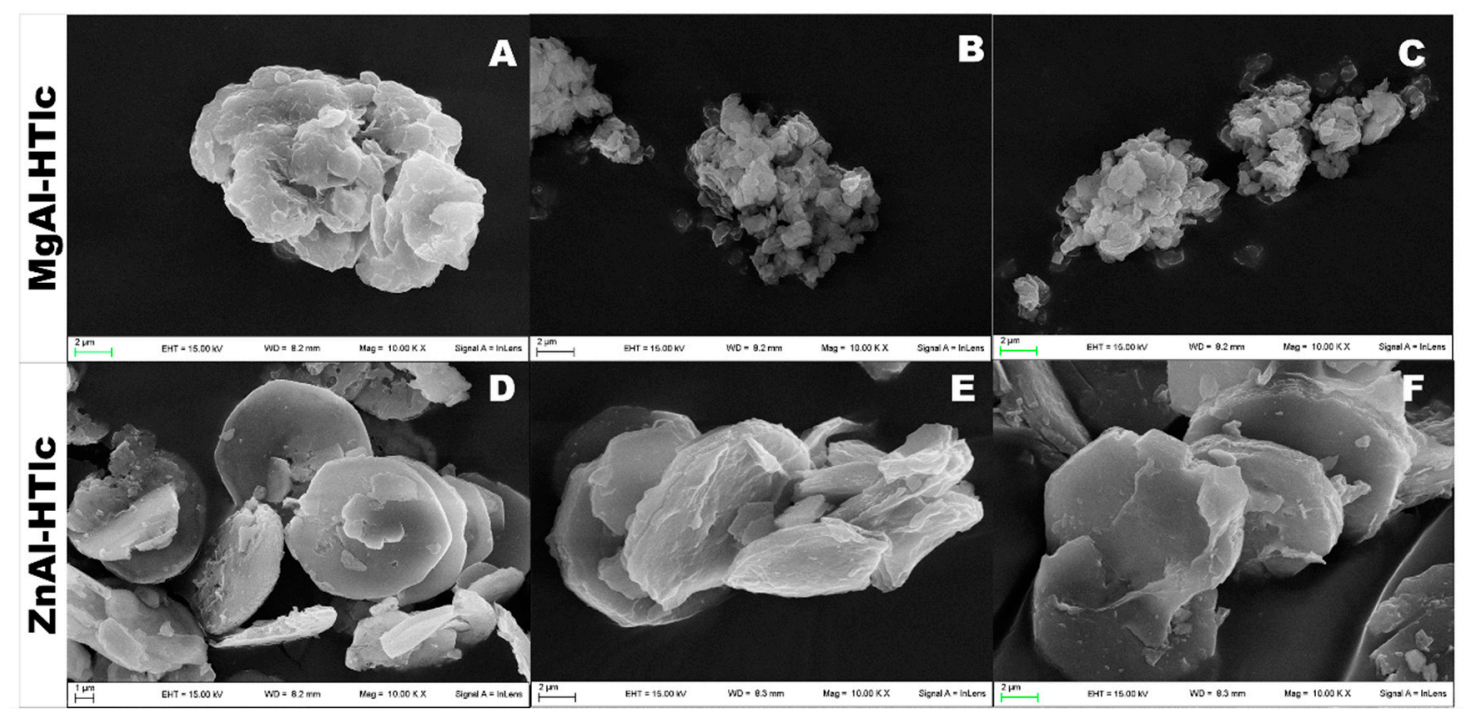

Figure 2. SEM micrographs of: (A) MgAl-Cl; (B,C) MgAl-ALA; (D) ZnAl-Cl; and (E,F) ZnAl-ALA. 
A further characterization consisted in the evaluation of the powder flow properties according to the method described in the Ph. Eur. $9^{\text {th }} \mathrm{Ed}$. [36]. Thus, the compressibility index (C.I) and Hausner ratio (H.R.) of MgAl-ALA, ZnAl-ALA, and crystalline ALA (used as control) were calculated by measuring the bulk and tapped volume.

Crystalline ALA showed a very poor flow character, Table 2.9.36.-2—Scale of Flowability, Ph. Eur. $9^{\text {th }}$ Ed., with a compressibility index (C.I.) of 33.3 and a hausner ratio (H.R.) of 1.5. Once intercalated the flowability is enhanced, as demonstrated by the results obtained from MgAl-ALA (C.I: 9, H.R.:1.1, "Excellent") and ZnAl-ALA (C.I.:13, H.R.: 1.15, "Good").

\subsection{Study of Thermal Stability of ALA Samples by DSC Analysis}

Crystalline ALA and the hybrids (containing $5 \mathrm{mg}$ of ALA) were stored for $48 \mathrm{~h}$ at $25^{\circ} \mathrm{C}$ under 97\% RH [46]. Analyzing the thermograms of the samples before and after storage (Figure $3 \mathrm{~A}$ ) in the case of crystalline ALA, it is clearly visible a modification ascribable to the decrease of the crystallinity degree testified also by the decrease of the melting enthalpy $(\Delta \mathrm{H}=-123.88 \mathrm{~J} / \mathrm{g})$. While in the case of both hybrids, no modifications are detectable (Figure 3B).
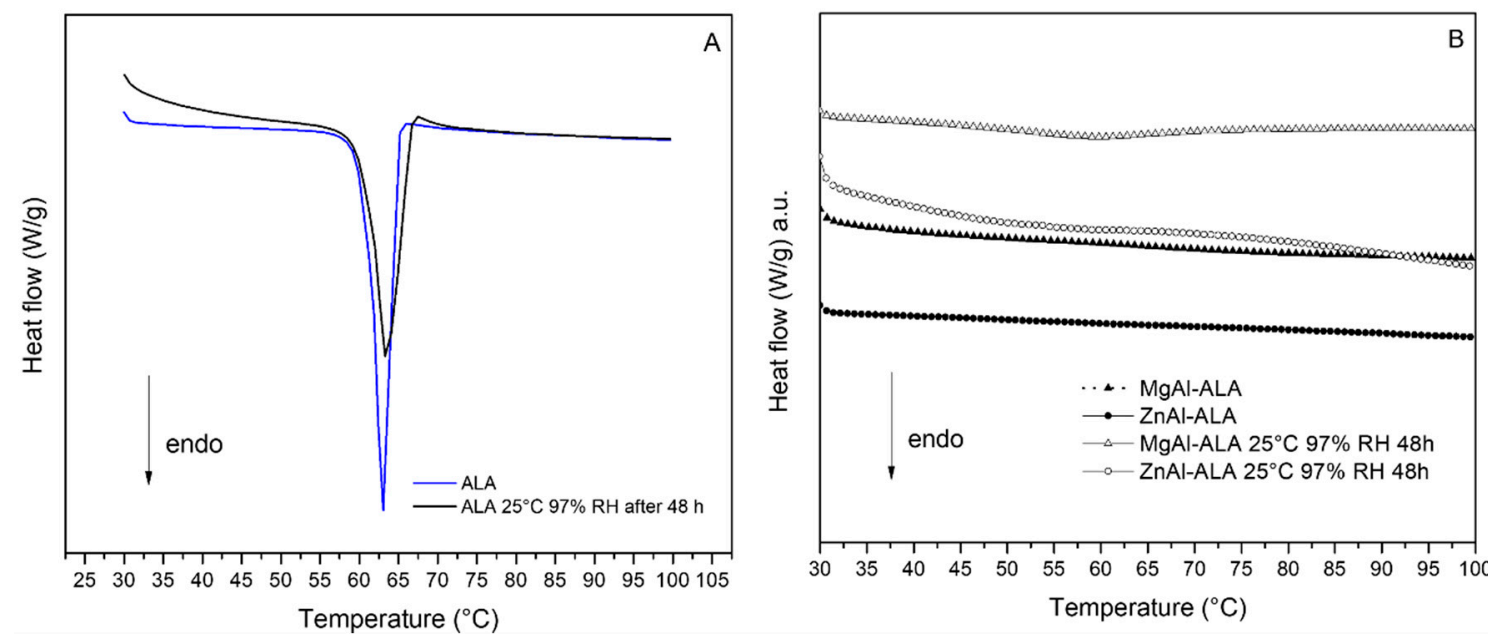

Figure 3. Thermograms obtained before and after storage at $25^{\circ} \mathrm{C}$ for $48 \mathrm{~h} 97 \% \mathrm{RH}$ of: (A) crystalline ALA; (B) MgAl-ALA and ZnAl-ALA, the spectra (B) are shown in arbitrary units (a.u.) and shifted for clarity.

\subsection{Hydrogel Composition Optimization}

ALA low water solubility limits the introduction in hydrophilic formulations. On the other hand, its dispersion in a hydrophilic base as fine powder is not a suitable strategy because the crystallinity degree undergoes modifications at high $\mathrm{RH}$ values as observed in the stability studies performed (par. 3.2). It is possible to hypothesize that a similar modification should take place when free ALA crystals are dispersed in a hydrophilic base with consequent product shelf-life decrease.

The promising preliminary results obtained from the hybrid stability studies opened the possibility to project a hydrophilic formulation for their topical application.

Based on that, the idea was to formulate the hybrids as a hydrogel, formulation of simple composition and easy to prepare, compared to an emulsion.

Among the formulations on the market containing ALA, Tiobec ${ }^{\circledR}$ cream (ALA 5\%) was chosen in this study for comparison.

The pre-formulation study started using a recipe reported in the Farmacopea Ufficiale Italiana XII Ed. [40] with the following composition: NaCMC 5\% (wt./wt.), glycerol 10\% (wt./wt.), and water until $100 \%$. 
Sorbitol was used in place of glycerol as literature studies demonstrated that its use such wetting agent/plasticizer improves hydrogel mechanical properties than glycerol [47].

In analogy with 5\% ALA loading of the commercial formulation Tiobec ${ }^{\circledR}$, the hydrogels were loaded with an amount of intercalation product containing $5 \% \mathrm{wt}$./wt. of ALA $(11.93 \%$ and $17.48 \%$ and for MgAl-ALA and ZnAl-ALA, respectively).

The water content of the original recipe was decreased in order to introduce free ALA (in crystalline form) or the intercalation product and $\mathrm{MgAl}-\mathrm{HTlc}-\mathrm{Cl}$ to reach the total HTlc amount of $17.48 \%$ wt./wt. when required.

The first hydrogel prototype prepared (P1, Table 1) resulted very viscous and disomogeneous. Its application makes the skin sticky with consequent unpleasant sensation. The high viscosity can be attributed to the combination of a high $\mathrm{NaCMC}$ percentage (5\%) with $\mathrm{MgAl}-\mathrm{Cl}$, well known rheological agent $[48,49]$. Thus, new prototypes were prepared reducing the amount of NaCMC (P2-P4, Table 1). By this modification, the consistency decreased however the problem of skin stickiness persisted. This may therefore be attributed to the adhesive properties of $\mathrm{NaCMC} \mathrm{[50].} \mathrm{In} \mathrm{order} \mathrm{to} \mathrm{solve} \mathrm{the}$ problem, NaCMC was replaced by hydroxyethyl cellulose (HEC), another cellulose derivative largely used in the preparation of topical gels intended for skin application. Thus, hydrogels with different percentages of HEC were prepared (P5-P8, Table 1).

A primary evaluation about these formulations was made on the basis of: (i) easiness of manufacturing procedure, (ii) final formulation aspect (Figure S3) and its sensorial effect after application. The most suitable hydrogel resulted by using 1.75\% of HEC (P7, Table 1). In order to make the formulations comparable, in the hydrogels containing free ALA and MgAl-ALA, MgAl-Cl was added to reach the final content of $17.48 \%$ (wt./wt.) in reference of the ZnAl-ALA amount (Table 2).

A preliminary observation evaluation of the prepared hydrogels, MgAl-ALA-H and ZnAl-ALA-H, compared to the commercial Tiobec ${ }^{\circledR}$, showed that the latter formulation is discontinuous with visible particles while the prepared hydrogels appear uniform of pleasant appearance. MgAl-ALA-H and ZnAl-ALA-H hydrogels appear uniformly matt, while ALA-H showed a slight chromatic discontinuity (Figure S4) suggesting the instability free ALA. For this reason, ALA-H was not considered suitable to be analyzed in the following rheological and release studies.

\subsection{Rheological Characterization}

The viscosity of hydrogels containing MgAl-ALA and ZnAl-ALA (Table 2) was measured at $25^{\circ} \mathrm{C}$ (storage temperature) and $32^{\circ} \mathrm{C}$ (skin surface temperature) and compared to that obtained from the commercial formulation Tiobec ${ }^{\circledR}$.

The flow profiles of hydrogels were investigated by the rheological data fitting to the power law model [51] (Equation (3)):

$$
\eta=m(\dot{\gamma})^{n-1}
$$

where:

$$
\begin{array}{ll}
- & \eta=\text { viscosity } \\
- & \mathrm{m}=\text { is a constant represented by the } \log \eta \text { value when } \log \gamma=0 \\
- & \gamma=\text { shear rate } \\
- & \mathrm{n}=\text { power-law index. }
\end{array}
$$

The $\mathrm{n}$ value is related to the degree of pseudoplastic or shear thinning behavior. Values of $\mathrm{n}<1$ identify shear-thinning behavior while $\mathrm{n}>1$ identify a shear-thickening behavior. According to Equation (3), the logarithm of viscosity ( $\eta$ ) vs. the logarithm of shear rate $(\gamma)$ curve, can be approximated by a line over a certain range of shear rate values and $n-1$ represents the slope of the obtained line.

The rheological measurements performed showed a shear thinning (pseudoplastic) behaviour for MgAl-ALA-H, ZnAl-ALA-H, and Tiobec ${ }^{\circledR}$ (Figure 4A,B). The latter resulted the more viscous showing a limited flowing under solicitation, as demonstrated by the narrow shear rate range $\left(0.05-4.39 \cdot 10^{2} 1 / \mathrm{s}\right)$. 
The better flowing properties of hydrogels containing the intercalation products are testified by shear rate values ranging between $0.05-16.77 \cdot 10^{3} 1 / \mathrm{s}$ and $0.05-14.00 \cdot 10^{3} 1 / \mathrm{s}$ for MgAl-ALA-H and ZnAl-AlA-H, respectively.
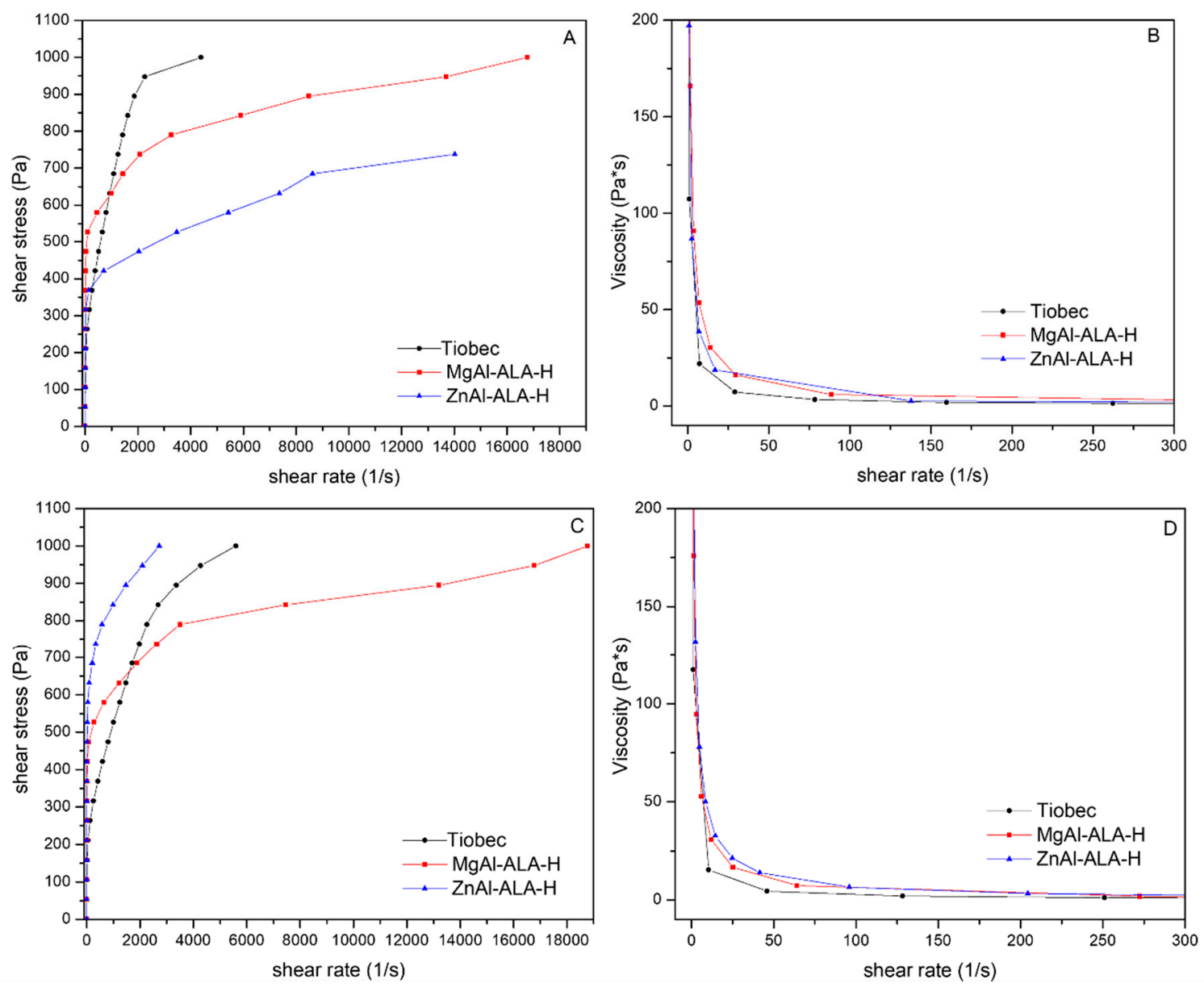

Figure 4. Shear stress vs. shear rate for hydrogels MgAl-ALA-H, ZnAl-ALA-H, and Tiobec ${ }^{\circledR}$ at: $25^{\circ} \mathrm{C}$ (A) and $32{ }^{\circ} \mathrm{C}(\mathrm{C})$; Viscosity vs. shear rate for hydrogels MgAl-ALA-H, ZnAl-ALA-H, and Tiobec ${ }^{\circledR}$ at $25^{\circ} \mathrm{C}(\mathbf{B})$ and $32{ }^{\circ} \mathrm{C}(\mathbf{D})$.

By application of the power law model the power-law index " $n$ " resulted $<1$ in all cases ( $n=0.85$ for Tiobec ${ }^{\circledR}, \mathrm{n}=0.52$ for MgAl-ALA-H and $\mathrm{n}=0.72$ for ZnAl-ALA-H) testifying the shear-thinning behavior of the hydrogels, more pronounced in the case of MgAl-ALA-H.

In the case of Tiobec ${ }^{\circledR}$ the flow index is close to 1 suggesting that this formulation could pass easily from a shear thinning to a shear thickening behavior.

Increasing the temperature to $32{ }^{\circ} \mathrm{C}$ (skin surface temperature) the flowing character of the commercial product Tiobec ${ }^{\circledR}$ resulted almost similar to $25{ }^{\circ} \mathrm{C}$ (shear rate range $0.05-5.59 \cdot 10^{2} 1 / \mathrm{s}$ ). As expected, the increase of the temperature produced an increase of the flow properties for MgAl-ALA-H (shear rate range 0.05-18.77·10 1/s) (Figure 4C,D).

The application of the power law model showed that the power-law index " $n$ " resulted $<1$ also in this case. The temperature increase from $25^{\circ} \mathrm{C}$ to $32{ }^{\circ} \mathrm{C}$ brought a small decrease of " $\mathrm{n}$ " value for Tiobec $^{\circledR}(\mathrm{n}=0.74)$ and for MgAl-ALA-H $(\mathrm{n}=0.47)$.

The enhanced flow properties of MgAl-ALA-H are ascribable to the presence of HTlc in the hydrogels and particularly to the lamellar structure. In fact, under mechanical solicitations (shear stress force), the lamellae orientate themselves in the direction of flow and this is responsible for the softening behavior of the formulation. This aspect is very important as the presence of HTlc makes the formulation easy to apply on the skin giving at the same time a pleasant touch sensation. 
On the other hand, in the case of ZnAl-ALA-H a decrease of flowing was observed (shear rate range $0.05-2.72 \cdot 10^{3} 1 / \mathrm{s}$ ) compared to $25^{\circ} \mathrm{C}$ (Figure $4 \mathrm{~B}$ ).

The application of the power law model showed an increase of the power-law index $(\mathrm{n}=0.88)$ in comparison to $25^{\circ} \mathrm{C}$. These results suggest that increasing the temperature this hydrogel become stiff. This phenomenon can be ascribed to the lost of a small amount of water due to the temperature increase $\left(+7^{\circ} \mathrm{C}\right)$ and to the fraction of $\mathrm{ZnAl}$-ALA particles dispersed in the hydrogel.

This phenomenon, observed only for ZnAl-ALA-H, can be ascribable to two main factors: (i) The lower charge density of ZnAl-ALA particles vs. MgAl-ALA due to the different aluminum content [52], $\mathrm{Al}_{0.38}$ vs. $\mathrm{Al}_{0.40}$ for $\mathrm{ZnAl}-\mathrm{ALA}$ and $\mathrm{MgAl}$-ALA respectively, as demonstrated by the formulae: $\left[\mathrm{Zn}_{0.62} \mathrm{Al}_{0.38}(\mathrm{OH})_{2}\right](\mathrm{Cl})_{0.15}(\mathrm{ALA})_{0.23} \cdot 1.56 \mathrm{H}_{2} \mathrm{O}$ and $\left[\mathrm{Mg}_{0.60} \mathrm{Al}_{0.40}(\mathrm{OH})_{2}\right](\mathrm{Cl})_{0.09}(\mathrm{ALA})_{0.31}$ - $1.45 \mathrm{H}_{2} \mathrm{O}$. The higher charge density for MgAl-ALA means that the electrostatic interactions between HTlc and water molecules increases (ii) the different morphology of the hybrids crystals. In fact, as observed in the micrographs reported in Figure 2, MgAl-ALA crystals expose a higher surface due to the "desert rose like structure" in comparison to ZnAl-ALA flat crystals. This allows the highest electrostatic interactions with water molecules limiting the evaporation.

The analysis of the formulations made by an optical microscope (Figure 5) showed that ZnAl-ALA particles are smaller and more homogeneously dispersed in the hydrogel (Figure 5D) than MgAl-ALA (Figure 5C), this is confirmed also by the particle size distributions obtained by SPOS analysis (Figure S2). ZnAl-ALA exposes a greater surface area than MgAl-ALA that could be responsible for the formation of bonds between HEC network and HTlc microcrystals giving rise to a reinforced gel network structure.
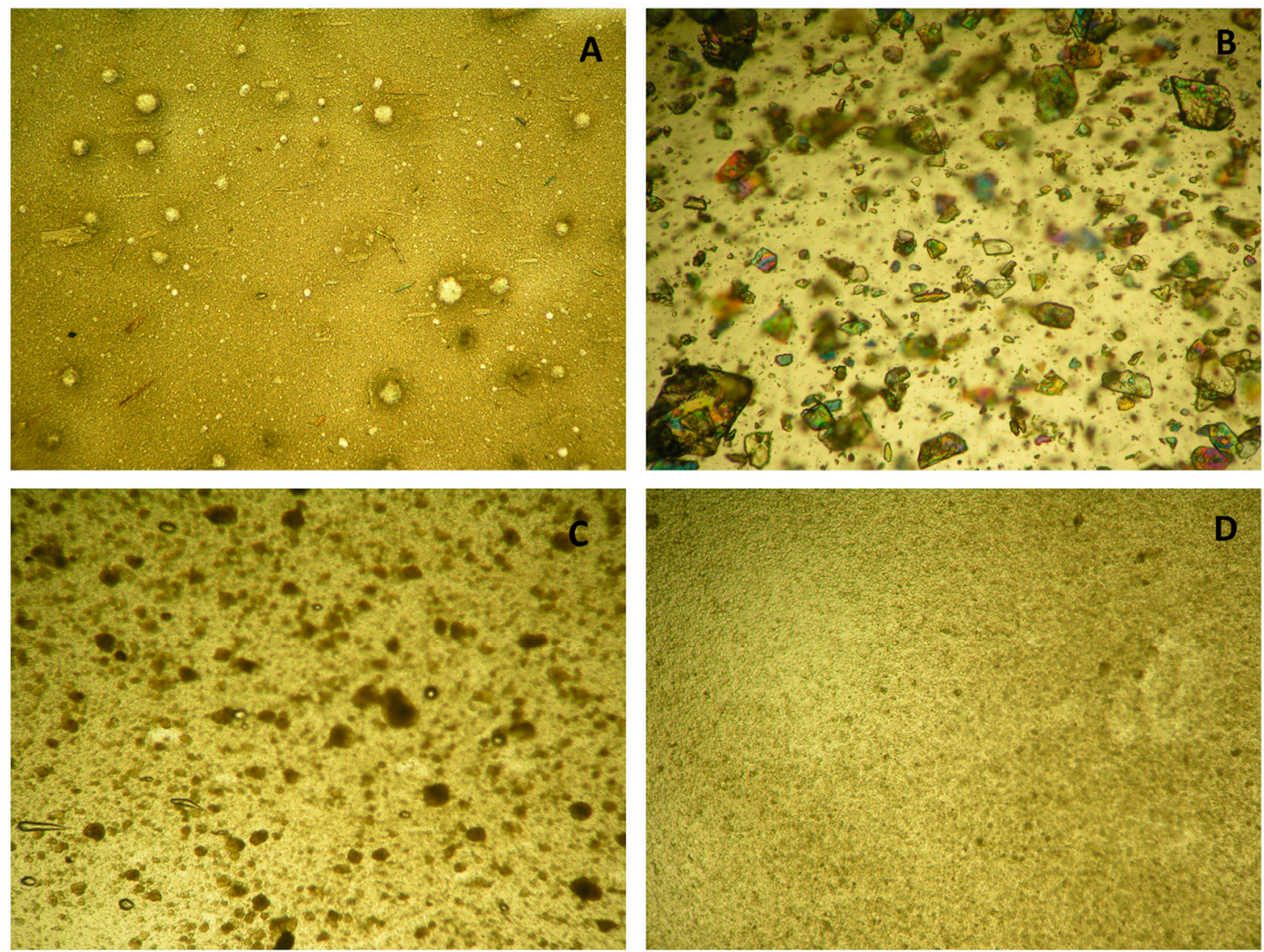

Figure 5. Pictures obtained using an optical microscope: (A) Tiobec ${ }^{\circledR}$; (B) ALA-H; (C) MgAl-ALA-H, and (D) ZnAl-ALA. 


\subsection{Spreadability Measurement}

Spreadability assay was performed using one gram of formulation (Tiobec ${ }^{\circledR}, \mathrm{MgAl}-\mathrm{ALA}-\mathrm{H}$ and ZnAl-ALA-H) using the method described by Arvouet-Grand et al. [41]. The obtained results showed that Tiobec ${ }^{\circledR}$ produced the lowest spread diameter $(40 \mathrm{~mm}$, Figure $6 \mathrm{~A}$ ) resulting $<50 \mathrm{~mm}$ and for this reason considered as semi-stiff cream. After spreading the formulation is not uniform as it is hardly visible in the separation phase (Figure 6A, orange row).
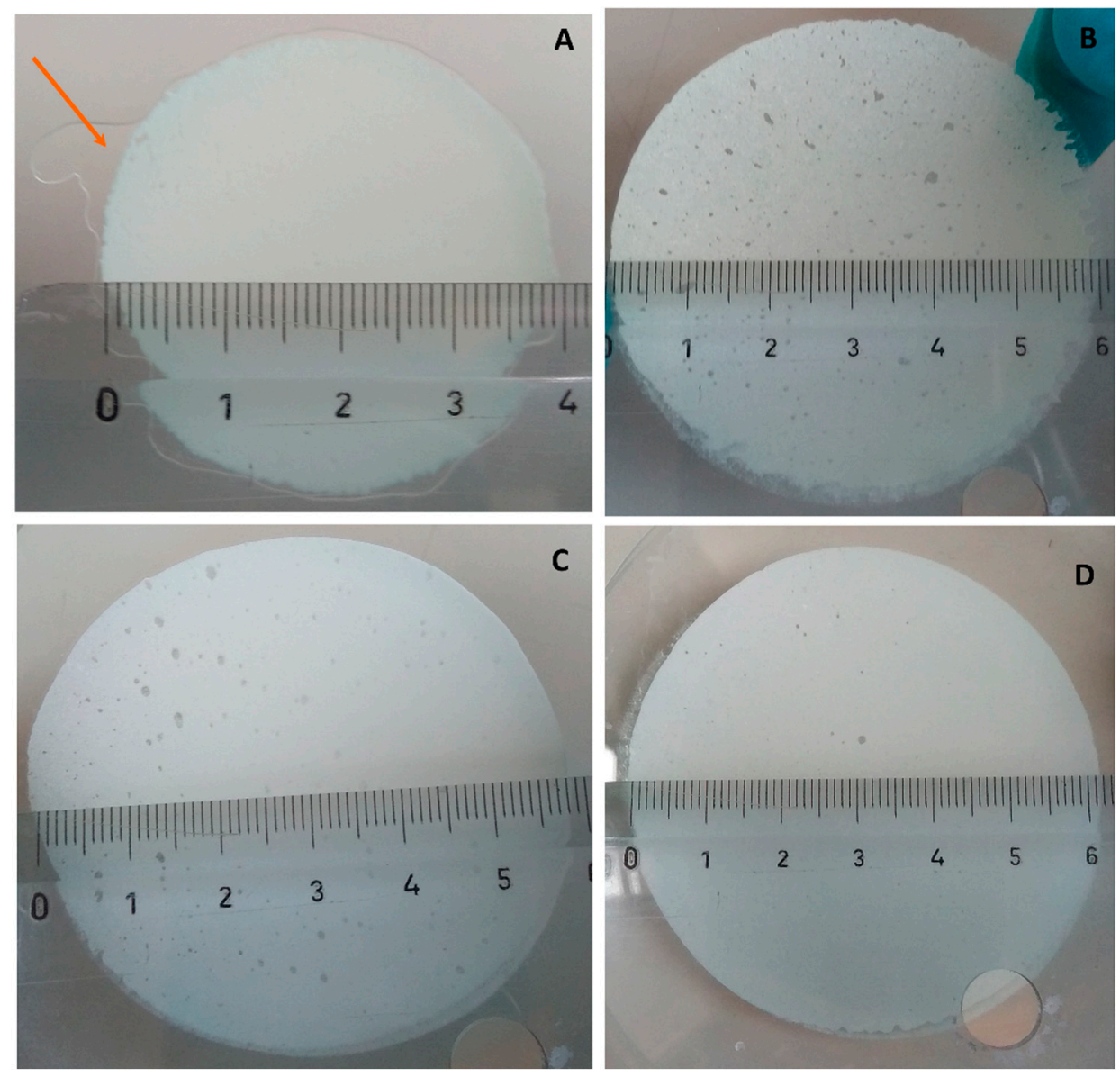

Figure 6. Spread diameter obtained from (A) Tiobec ${ }^{\circledR}$; (B) ALA-H; (C) MgAl-ALA-H and (D) ZnAl-ALA.

ALA-H produced a $60 \mathrm{~mm}$ spread diameter, however the formulation appears disomogenous with particles dispersed in the base (Figure 6B).

In the case of hydrogels containing the hybrids, a highest spread diameter was measured: $58 \mathrm{~mm}$ for MgAl-ALA-H (Figure 6C) and $62 \mathrm{~mm}$ ZnAl-ALA-H (Figure 6D). These values identify the developed hydrogels as semifluid [35,36].

Additionally further differences must be highlighted between MgAl-ALA-H and ZnAl-ALA-H. In fact hybrid particles are visible in the case of MgAl-ALA-H (as also observed in the picture reported in Figure 5C obtained from the optical microscope) differently form ZnAl-ALA-H. This can be explained considering the different particle size of the two hybrids (Figure S2). By the analysis of the cumulative distributions can be noticed that, in the case of MgAl-ALA, about $25 \%$ of particles shows a diameter $>40 \mu \mathrm{m}$ while in the case of ZnAl-ALA 95\% $<26.46 \mu \mathrm{m}$. This suggests that the particles dispersed and visible in the hydrogel MgAl-ALA-H are represented by the fraction $>40 \mu \mathrm{m}$. 


\subsection{Stability Studies of Hydrogels to Temperature}

The stability studies carried out on the commercial Tiobec ${ }^{\circledR}$ and the prepared formulations showed interesting results (Table 3). In fact, at the end of all the programmed cycles (see. Par. 2.19 method section) Tiobec ${ }^{\circledR}$ showed an evident phase separation and strong sulfurous odor testifying the instability of both formulation and the active ingredient (ALA). The hydrogel containing free ALA (ALA-H) showed modifications ascribable to the degradation of the active ingredient while the formulation containing the intercalation products did not show modifications (Table 3). The hydrogels containing hybrids resulted in stable and no sulfurous odor was felt, demonstrating that ALA is preserved from degradation when intercalated between the interlamellar nanosized space of HTlc, thanks to the host protective effect (Table 3).

Table 3. Observations after eight $4{ }^{\circ} \mathrm{C} / 45^{\circ} \mathrm{C}$ cycles of $48 \mathrm{~h}$.

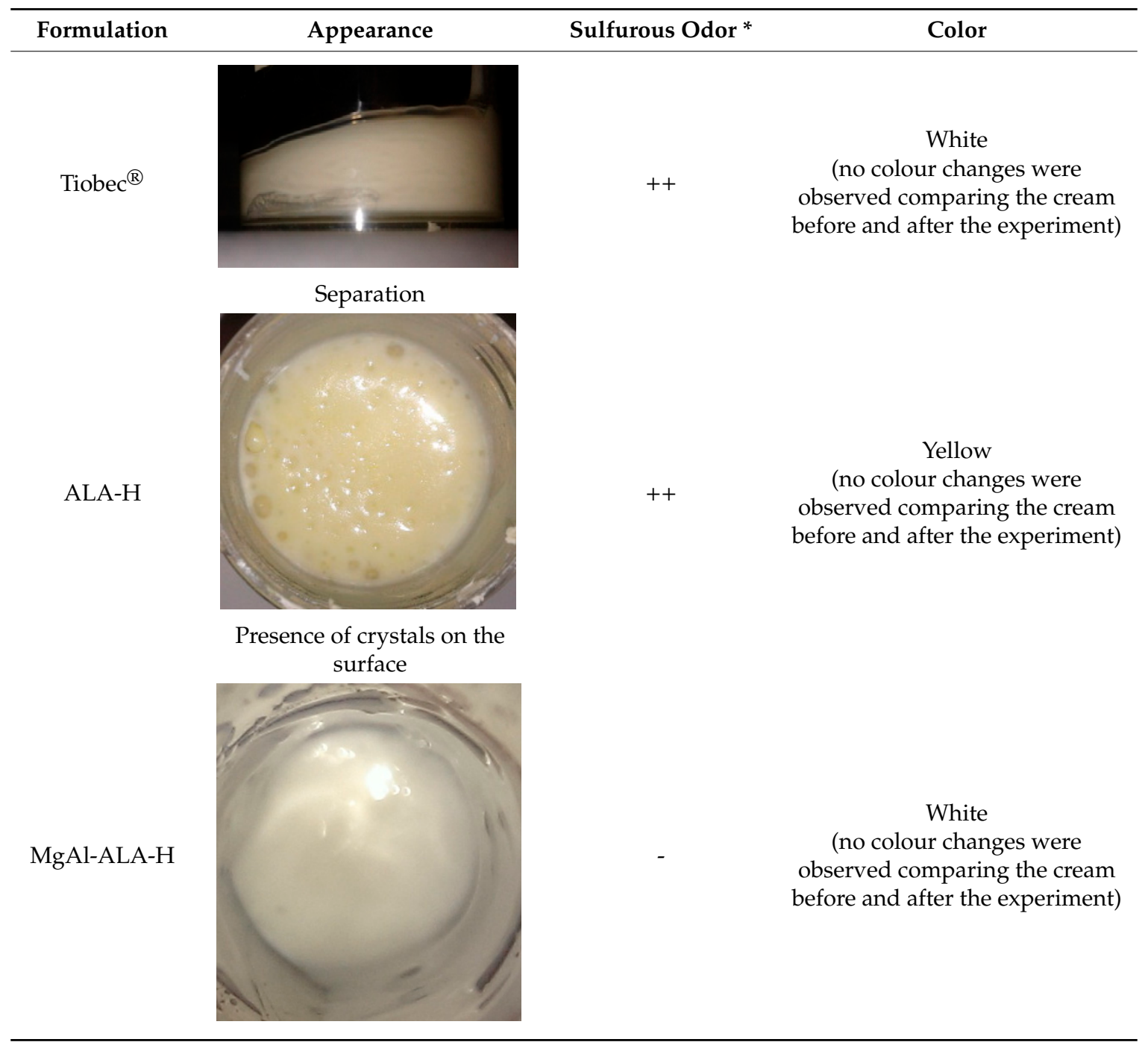


Table 3. Cont.

\begin{tabular}{|c|c|c|c|}
\hline Formulation & Appearance & Sulfurous Odor * & Color \\
\hline ZnAl-ALA-H & & - & $\begin{array}{l}\text { White } \\
\text { (no colour changes were } \\
\text { observed comparing the cream } \\
\text { before and after the experiment) }\end{array}$ \\
\hline
\end{tabular}

${ }^{*}$ none $(-)$, slight $(+)$, high $(++)$.

\subsection{MTT Test}

ALA promotes skin suppleness and anti-aging effect by enhancing the biosynthesis of new collagen in normal human dermal fibroblasts [53-55]. For this reason, it was interesting to evaluate the effect of the two hybrids on this cell line. MgAl-ALA and ZnAl-ALA were incubated with the culture medium DMEM for $24 \mathrm{~h}$ at $37^{\circ} \mathrm{C}$. After this time the supernatant was recovered (see method section) and incubated with cells. The obtained results highlighted that there is a difference between the two hybrids. In fact, in the case of ZnAl-ALA, cell viability resulted $<60 \%$ for the two highest concentrations. Moreover as observed in the graph (Figure 7) the remaining concentrations produced values of cell viability in the range of $60 \%-75 \%$. In the case of MgAl-ALA, cells viability resulted $>60 \%$ at all the assayed concentrations.

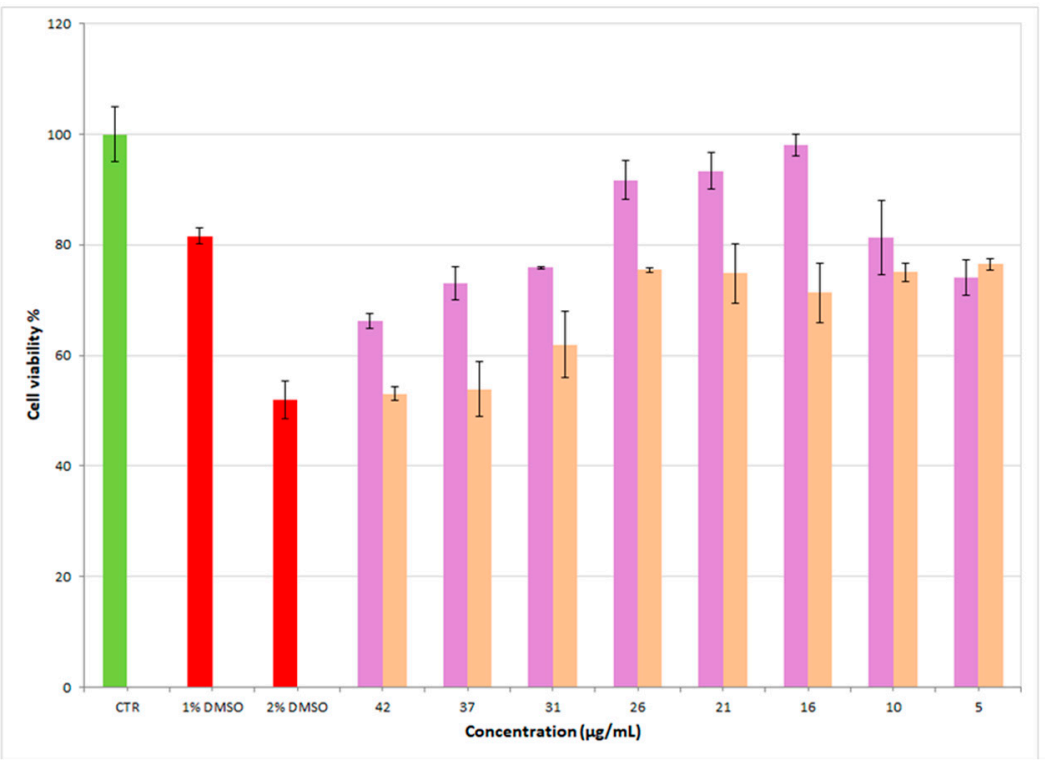

Figure 7. Effect on primary dermal fibroblasts viability incubated with different concentrations of supernatants (diluted with DMEM) deriving from the contact between MgAl-ALA (pink bars) or ZnAl-ALA (orange bars) and DMEM ( $\mathrm{n}=3, \pm \mathrm{SD}$ ). DMEM was used as negative control (CTR with $100 \%$ of cell viability) and DMSO, known to induce cell death, used as a positive control with two different concentrations.

The differences observed between the hybrids can be ascribed to the different nature of the divalent cation in the lamellae of HTlc. In fact, as observed in a previous study [56], it can be hypothesized that an important amount of $\mathrm{Zn}$ ions solubilezes after the contact of ZnAl-ALA with the culture medium, 
generally devoid of this element, resulting toxic for cells $[57,58]$. These results suggest that the use of $\mathrm{MgAl}-\mathrm{ALA}$ is more preferable than ZnAl-ALA.

\subsection{In Vitro Release Capability}

At first an in vitro study was carried out using the vertical Franz diffusion cell in order to evaluate ALA release profile from the prepared hydrogels. However some problems were encountered as within $24 \mathrm{~h}$ a very low amount of ALA was released from both hydrogels $(10.23 \%$ and $11.8 \%$ for MgAl-ALA-H and ZnAl-ALA-H, respectively, Figure S5). A recent study demonstrated ALA molecules capability to form micelles in aqueous solutions [59] and this can justify the very low ALA amount measured after $24 \mathrm{~h}$. In order to better investigate this result, a different experiment was planned based on a previous work [25]. In order to evaluate the real ability (of both intercalation products) to release ALA molecule by ion exchange mechanisms, a fixed amount of MgAl-ALA (238.7 mg) and ZnAl-ALA (249.65 mg), corresponding to $100 \mathrm{mg}$ of ALA, was dispersed under magnetic stirring (600 rpm) in a mixture of $\mathrm{MeOH} / \mathrm{K}_{2} \mathrm{CO}_{3}(30 / 70)$ at $32{ }^{\circ} \mathrm{C}$ for $24 \mathrm{~h}$. After this time, the solid was recovered by filtration dried in oven at $37^{\circ} \mathrm{C}$ for 48 hours and then submitted to X-ray analysis. The obtained results showed that ALA molecules are completely exchanged after $24 \mathrm{~h}$ by carbonate anions (Figure S6A) in the case of MgAl-ALA, as testified by the reflection at $\mathrm{d}=0.76 \mathrm{~nm}$ typical of carbonate anion [33]. In the case of ZnAl-ALA, the exchange was not complete as testified by the co presence of the reflections at $\mathrm{d}=2.2 \mathrm{~nm}$ (ALA) and $\mathrm{d}=0.76 \mathrm{~nm}$ of the carbonate anion (Figure S6B).

\section{Conclusions}

ALA intercalation into HTlc is a suitable strategy as the molecule stabilization is obtained. This is particularly interesting considering that the stabilization is also maintained when the hybrid product is introduced in hydrogel formulations. In fact, free ALA is not stable in the same kind of formulation.

Moreover, the use of the hybrid improved the formulation rheological properties and the stability of the formulation. In vitro experiments performed on fibroblasts showed that MgAl-ALA hybrid was more safe than ZnAl-ALA, making it better to be used for skin application.

The obtained results suggest that the purposed technology, namely ALA intercalation into HTlc, and its formulation as hydrogel represent a valuable alternative to the commercial formulations actually available on the market.

Supplementary Materials: The following are available online at http://www.mdpi.com/2079-9284/6/2/35/s1, Figure S1: XRPD of: (A) MgAl-Cl and MgAl-ALA; (B) ZnAl-Cl and ZnAl-ALA, Figure S2: Dimensional distribution obtained by SPOS analysis of MgAl-Cl, ZnAl-Cl, MgAl-ALA and ZnAl-ALA, Figure S3: Aspect of hydrogels prepared using HEC in different percentages: $2.50 \%$ (P5), 2.00\% (P6), $1.75 \%$ (P7) and $1.25 \%(\mathrm{P} 8)$, Figure S4: Aspect of (A) Tiobec®and hydrogels loaded with (B) crystalline ALA; (C) MgAl-ALA and (D) ZnAl-ALA, Figure S5: ALA release profiles obtained in methanol and phosphate buffer $\mathrm{pH} 5.5(25 / 75 \mathrm{v} / \mathrm{v})$ at $32{ }^{\circ} \mathrm{C}$ from ZnAl-ALA-H and MgAl-ALA-H, Figure S6: XRPD patterns of: (A) MgAl-ALA before (a) and after the contact with a $\mathrm{MeOH} / \mathrm{K} 2 \mathrm{CO} 3(30 / 70)$ solution at $32{ }^{\circ} \mathrm{C}$ for $24 \mathrm{~h}$ (b); (B) ZnAl-ALA before (a) and after the contact with a $\mathrm{MeOH} / \mathrm{K} 2 \mathrm{CO} 3(30 / 70)$ solution at $32{ }^{\circ} \mathrm{C}$ for $24 \mathrm{~h}(\mathrm{~b})$.

Author Contributions: Conceptualization, T.B., M.R. and L.P.; Formal analysis, C.P., P.C. and M.R.C.; Investigation, T.B., M.R. and L.P.; Methodology, C.P.; Project administration, L.P.; Writing - original draft, C.P., P.C. and L.P.

Funding: This research received no external funding.

Acknowledgments: Authors sincerely acknowledge: from the Department of Pharmaceutical Sciences Morena Nocchetti for X-ray patterns registration and Marco Marani for technical assistance; Alessandro Di Michele from the Department of Physics and Geology for SEM micrographs.

Conflicts of Interest: The authors declare no conflict of interest. 


\section{References}

1. Kramer, K.; Hoppe, P.P.; Packer, L. R $\alpha$ Lipoic acid. In Nutraceuticals in Health and Disease Prevention; Dekker, M., Ed.; CRC Press: New York, NY, USA, 2001; pp. 273-275.

2. Solmonson, A.; De Berardinis, R.J. Lipoic acid metabolism and mitochondrial redox regulation. J. Biol. Chem. 2018, 293, 7522-7530. [CrossRef] [PubMed]

3. Beitner, H. Randomized, placebo-controlled, double blind study on the clinical efficacy of a cream containing $5 \% \alpha$-lipoic acid related to photoageing of facial skin. Br. J. Dermatol. 2003, 149, 841-849. [CrossRef] [PubMed]

4. Oresajo, C.; Pillai, S.; Manco, M.; Yatskayer, M.; McDaniel, D. Antioxidants and the skin: Understanding formulation and efficacy. Dermatol. Ther. 2012, 25, 252-259. [CrossRef] [PubMed]

5. Sikdar, S.; Papadopoulou, M.; Dubois, J. Effect of $\alpha$-lipoic acid on proteasomal induction: Protection against oxidative damage in human skin fibroblasts cell line NHDF. Pharmacol. Pharm. 2017, 8, 292-305. [CrossRef]

6. Matsugo, S.; Yan, L.J.; Han, D.; Trischler, H.J.; Packer, L. Elucidation of antioxidant activity of $\alpha$-lipoic acid toward hydroxyl radical. Biochem. Biophys. Res. Commun. 1995, 208, 161-167. [CrossRef] [PubMed]

7. Lipinski, B. Hydroxyl radical and its scavengers in health and disease. Oxid. Med. Cell. Longev. 2011, 5, 809696. [CrossRef] [PubMed]

8. Davis, G.D.; Masilamoni, J.G.; Arul, V.; Kumar, M.S.; Baraneedharan, U.; Paul, S.F.; Sakthivelu, I.V.; Jesudason, E.P.; Jayakumar, R. Radioprotective effect of DL- $\alpha$-lipoic acid on mice skin fibroblasts. Cell Biol. Toxicol. 2009, 25, 331-340. [CrossRef]

9. Li, G.; Fu, J.; Zhao, Y.; Ji, K.; Luan, T.; Zang, B. Alpha-lipoic acid exerts anti-inflammatory effects on lipopolysaccharide-stimulated rat mesangial cells via inhibition of nuclear factor kappa B (NF- $\mathrm{kB}$ ) signaling pathway. Inflammation 2015, 38, 510-519. [CrossRef]

10. Moura, F.A.; De Andrade, K.Q.; Dos Santos, J.C.F.; Goulart, M.O.F. Lipoic acid: Its antioxidant and anti-inflammatory role and clinical applications. Curr. Top. Med. Chem. 2015, 15, 458-483. [CrossRef]

11. Yıldırım Baş, F.; Bayram, D.; Arslan, B.; Armağan, I.; Yeşilot, S.; Çiçek, E.; Yorgancıgil, E. Effect of alpha lipoic acid on smoking-induced skin damage. Cutan. Ocul. Toxicol. 2017, 36, 67-73. [CrossRef]

12. Sugimoto, K.; Nishiura, H.; Yamaguchi, Y.; Hirata, K.; Kubota, Y. $\alpha$-Lipoic Acid Nanoparticles and Methods for Preparing Thereof. U.S. Patent 9,079,874, 14 July 2015.

13. Li, Y.X.; Park, E.Y.; Lima, S.T. Stabilization of alpha-lipoic acid by complex formation with octenylsuccinylated high amylose starch. Food Chem. 2018, 242, 389-394. [CrossRef] [PubMed]

14. Xia, N.; Liu, T.; Wang, Q.; Xia, Q.; Bian, X. In vitro evaluation of alpha-lipoic acid loaded lipid nanocapsules for topical delivery. J. Microencapsul. 2017, 34, 571-581. [CrossRef] [PubMed]

15. Kubota, Y.; Musashi, M.; Nagasawa, T.; Shimura, N.; Igarashi, R.; Yamaguchi, Y. Novel nanocapsule of $\alpha$-lipoic acid reveals pigmentation improvement: $\alpha$-Lipoic acid stimulates the proliferation and differentiation of keratinocyte in murine skin by topical application. Exp. Dermatol. 2019, 28, 55-63. [CrossRef] [PubMed]

16. Kulkamp-Guerreiro, I.C.; Terroso, T.F.; Assumpção, E.R.; Berlitz, S.J.; Contri, R.V.; Pohlmann, A.R.; Guterres, S.S. Development and stability of innovative semisolid formulations containing nanoencapsulated lipoic acid for topical use. J. Nanosci. Nanotechnol. 2012, 12, 7723-7732. [CrossRef] [PubMed]

17. Segall, A.; Sosa, M.; Alami, A.; Enero, C.; Hormaechea, F.; Pizzorno, M.T.; Bregni, C.; Serrao, R. Stability study of lipoic acid in the presence of vitamins $\mathrm{A}$ and $\mathrm{E}$ in o/w emulsions for cosmetic application. J. Cosmet. Sci. 2004, 55, 449-461. [CrossRef] [PubMed]

18. Zheng, K.; Zou, A.; Yang, X.; Liu, F.; Xia, Q.; Ye, R.; Mu, B. The effect of polymer-surfactant emulsifying agent on the formation and stability of $\alpha$-lipoic acid loaded nanostructured lipid carriers (NLC). Food Hydrocoll. 2013, 32, 72-78. [CrossRef]

19. Takahashi, H.; Bungo, Y.; Mikuni, K. The Aqueous solubility and thermal stability of $\alpha$-lipoic acid are enhanced by cyclodextrin. Biosci. Biotechnol. Biochem. 2011, 75, 633-637. [CrossRef] [PubMed]

20. Kofuji, K.; Nakamura, M.; Isobe, T.; Murata, Y.; Kawashima, S. Stabilization of $\alpha$-lipoic acid by complex formation with chitosan. Food Chem. 2008, 109, 167-171. [CrossRef]

21. Kofuji, K.; Isobe, T.; Murata, Y. Controlled release of alpha-lipoic acid through incorporation into natural polysaccharide-based gel beads. Food Chem. 2009, 115, 483-487. [CrossRef]

22. Li, Y.X.; Kim, Y.J.; Reddy, C.K.; Lee, S.J.; Lim, S.T. Enhanced bioavailability of alpha-lipoic acid by complex formation with octenylsuccinylated high-amylose starch. Carbohydr. Polym. 2019, 219, 39-45. [CrossRef] 
23. Perioli, L.; Ambrogi, V.; Nocchetti, M.; Sisani, M.; Pagano, C. Preformulation studies on host-guest composites for oral administration of BCS class IV drugs: HTlc and furosemide. Appl. Clay Sci. 2011, 53, 696-703. [CrossRef]

24. Pagano, C.; Tiralti, M.C.; Perioli, L. Nanostructured hybrids for the improvement of folic acid biopharmaceutical properties. J. Pharm. Pharmacol. 2016, 68, 1384-1395. [CrossRef] [PubMed]

25. Perioli, L.; Pagano, C. Inorganic matrices: An answer to low drug solubility problem. Exp. Opin. Drug Deliv. 2012, 9, 1559-1572. [CrossRef] [PubMed]

26. Conterosito, E.; Croce, G.; Palin, L.; Pagano, C.; Perioli, L.; Viterbo, D.; Boccaleri, E.; Paul, G.; Milanesio, M. Structural characterization and thermal and chemical stability of bioactive molecule-hydrotalcite (LDH) nanocomposites. Chem. Phys. 2013, 15, 13418-13433. [CrossRef] [PubMed]

27. Pagano, C.; Perioli, L.; Blasi, F.; Bastianini, M.; Chiesi, C.; Cossignani, L. Optimization of wine phenol extraction by layered double hydroxides and technological evaluation of the bioactive-rich powder. Int. J. Food Sci. Technol. 2017, 52, 2582-2588. [CrossRef]

28. Perioli, L.; Pagano, C.; Nocchetti, M.; Latterini, L. Development of smart semisolid formulations to enhance retinoic acid topical application. J. Pharm. Sci. 2015, 104, 3904-3912. [CrossRef]

29. Nae, H. Rheological properties of topical formulations (Chapter 11). In Handbook of Formulating Dermal Applications: A Definitive Practical Guide, 1st ed.; Dayan, N., Ed.; Scrivener Publishing LLC: Beverly, MA, USA, 2016.

30. Focke, W.W.; Molefe, D.; Labuschagne, F.J.W.; Ramjee, S. The influence of stearic acid coating on the properties of magnesium hydroxide, hydromagnesite, and hydrotalcite powders. J. Mater. Sci. 2009, 44, 6100-6109. [CrossRef]

31. Albiston, L.; Franklin, K.R.; Lee, E.; Smeulders, J.B. Rheology and microstructure of aqueous layered double hydroxide dispersions. J. Mater. Chem. 1996, 6, 871-877. [CrossRef]

32. Nakayama, H.; Wade, N.; Tsuhako, M. Intercalation of aminoacids and peptides into MgAl layered double hydroxide by recostruction method. Int. J. Pharm. 2004, 269, 469-478. [CrossRef]

33. Costantino, U.; Marmottini, F.; Nocchetti, M.; Vivani, R. New synthetic routes to hydrotalcite-like compounds-Characterisation and properties of the obtained materials. Eur. J. Inorg. Chem. 1998, 10, 1439-1446. [CrossRef]

34. Carr, R.L. Evaluating flow properties of solids. Chem. Eng. 1965, 72, 163-168.

35. Hausner, H.H. Friction conditions in a mass of metal powder. Int. J. Powder Metall. 1967, 3, 7-13.

36. European Directorate for the Quality of Medicines \& HealthCare (EDQM) Council of Europe. European Pharmacopoeia, 9th ed.; Density of Powders, Bulk Density and Tapped (Volume 1, Paragraph 2.9.34); EDQM Council of Europe: Strasburg, France, 2017.

37. Ceccarini, M.R.; Codini, M.; Cataldi, S.; Vannini, S.; Lazzarini, A.; Floridi, A.; Moretti, M.; Villarini, M.; Fioretti, B.; Beccari, T.; et al. Acid sphingomyelinase as target of Lycium Chinense: Promising new action for cell health. Lipids Health Dis. 2016, 15, 183-193. [CrossRef] [PubMed]

38. Ceccarini, M.R.; Vannini, S.; Cataldi, S.; Moretti, M.; Villarini, M.; Fioretti, B.; Albi, E.; Beccari, T.; Codini, M. In vitro protective effects of lycium barbarum berries cultivated in Umbria (Italy) on human hepatocellular carcinoma cells. BioMed Res. Int. 2016, 2016, 1-9. [CrossRef] [PubMed]

39. Greenspan, L. Humidity fixed points of binary saturated aqueous solutions. J. Res. 1977, 81, 89-96. [CrossRef]

40. Italian Health Ministry. Commissione permanente per la revisione e la pubblicazione della farmacopea ufficiale. Monograph "Gel base per preparazione semisolida per applicazione cutanea". In Italian Pharmacopoeia, 12th ed.; Istituto Poligrafico e Zecca Dello Stato: Roma, Italy, 2008; p. 1171.

41. Arvouet-Grand, A.; Vennat, B.; Lejeune, B.; Pourrat, A. Formulation of Propolis Extract Emulsions. I. O/W creams based on non-ionic surfactants and various consistency agents pages. Drug Dev. Ind. Pharm. 1995, 21, 1907-1915. [CrossRef]

42. Garg, A.; Aggarwal, D.; Garg, S.; Singla, A.K. Spreading of semisolid formulations an update. Pharm. Technol. N. Am. 2002, 26, 84-105.

43. The European Cosmetic. Toiletry and Perfumery Association (Colipa), Cosmetics Europe: Guidelines on Stability Testing of Cosmetic Products; The European Cosmetic: Lentilly, France, 2004.

44. Racz, C.P.; Santa, S.; Tomoaia-Cotisel, M.; Borodi, G.; Kacso, I.; Pirnau, A.; Bratu, I. Inclusion of a-lipoic acid in $\beta$-cyclodextrin. Physical-chemical and structural characterization. J. Incl. Phenom. Macrocycl. Chem. 2013, 76, 193-199. [CrossRef] 
45. European Directorate for the Quality of Medicines \& HealthCare (EDQM) Council of Europe. European Pharmacopoeia, 9th ed.; Fineness, Powder (Volume 1, Paragraph 2.9.35); EDQM Council of Europe: Strasburg, France, 2017.

46. Ikuta, N.; Sugiyama, H.; Shimosegawa, H.; Nakane, R.; Ishida, Y.; Uekaji, Y.; Nakata, D.; Pallauf, K.; Rimbach, G.; Terao, K.; et al. Analysis of the enhanced stability of R(+)-alpha lipoic acid by the complex formation with cyclodextrins. Int. J. Mol. Sci. 2013, 14, 3639-3655. [CrossRef]

47. Kozlowska, J.; Pauter, K.; Sionkowska, A. Carrageenan-based hydrogels: Effect of sorbitol and glycerin on the stability, swelling and mechanical properties. Polym. Test. 2018, 67, 7-11. [CrossRef]

48. Li, Y.; Bi, H.-Y.; Shen, S.-L.; Mao, X.-M.; Wang, C.-R.; Jin, Y.-S. Thixotropic behavior of hydrotalcite-like compound/cationic starch suspensions: Effects of mass ratio of hydrotalcite-like compound to cationic starch, electrolyte, and temperature. J. Disp. Sci. Technol. 2011, 32, 1239-1246. [CrossRef]

49. Perioli, L.; Pagano, C. Inorganic-organic hybrids to improve the performances of anti-inflammatory topical formulations. Int. J. Pharm. Res. Rev. 2016, 5, 1-18.

50. Kamel, S.; Ali, N.; Jahangir, K.; Shah, S.M.; El-Gendy, A.A. Pharmaceutical significance of cellulose: A review. Express Polym. Lett. 2008, 2, 758-778. [CrossRef]

51. Gupta, A.K.; Chhabra, R.P.; Irvine, T.F.; Capobianchi, M. Non-newtonian flows. In Handbook of Thermal Engineering, 2nd ed.; Chhafra, R.P., Ed.; CRC Press Taylor \& Francis Group: Boca Raton, FL, USA, 2017; pp. 229-230.

52. Young, Z.; Mata, V.; Rodrigues, A.E. Adsorption of carbon dioxide onto hydrotalcite-like compounds (HTlcs) at high temperatures. Ind. Eng. Chem. Res. 2001, 40, 204-209. [CrossRef]

53. Tsuji-Naito, K.; Ishikura, S.; Akagawa, M.; Saeki, H. $\alpha$-Lipoic acid induces collagen biosynthesis involving prolyl hydroxylase expression via activation of TGF- $\beta$-Smad signaling in human dermal fibroblasts. Connect. Tissue Res. 2010, 51, 378-387. [CrossRef] [PubMed]

54. Zhao, C.; Dai, L.; Wang, J.; Jian, Y.; Mei, Z.; Pei, X.; Xiong, X.; Yuan, W.; Wu, F. Beneficial effects of lipoic acid on post-burn hypertrophic scarring model. Int. J. Pharmacol. 2018, 14, 733-739.

55. Wang, X.; Wu, J. Modulating effect of fatty acids and sterols on skin aging. J. Funct. Foods 2019, 57, $135-140$. [CrossRef]

56. Pagano, C.; Perioli, L.; Latterini, L.; Nocchetti, M.; Ceccarini, M.R.; Marani, M.; Ramella, D.; Ricci, M. Folic acid-layered double hydroxides hybrids in skin formulations: Technological, photochemical and in vitro cytotoxicity on human keratinocytes and fibroblasts. Appl. Clay Sci. 2019, 168, 382-395. [CrossRef]

57. Choi, S.J.; Choy, J.H. Layered double hydroxide nanoparticles as target-specific delivery carriers: Uptake mechanism and toxicity. Nanomedicine 2011, 6, 803-814. [CrossRef] [PubMed]

58. Pandurangan, M.; Kim, D.H. In vitro toxicity of zinc oxide nanoparticles: A review. J. Nanopart. Res. 2015, 17, 1-8. [CrossRef]

59. Nishiura, H.; Sugimoto, K.; Akiyama, K.; Musashi, M.; Kubota, Y.; Yokoyama, T.; Yamashita, Y.; Kuriki, T.; Yamaguchi, Y. A novel nano-capsule of $\alpha$-lipoic acid as a template of core-shell structure constructed by self-assembly. J. Nanomed. Nanotechol. 2013, 4, 2. [CrossRef]

(C) 2019 by the authors. Licensee MDPI, Basel, Switzerland. This article is an open access article distributed under the terms and conditions of the Creative Commons Attribution (CC BY) license (http://creativecommons.org/licenses/by/4.0/). 